\title{
Adsorption of nickel by Indian soils
}

\author{
V. Ramachandran ${ }^{1 *}$, S.F. D’Souza ${ }^{1}$ \\ ${ }^{1}$ Nuclear Agriculture and Biotechnology Division. Bhabha Atomic Research Centre, Trombay, Mumbai 400 085, India. \\ *Corresponding author: vrchand@barc.gov.in
}

\begin{abstract}
:
Adsorption of metals from liquid into solid phase is one of the most important chemical processes which affect the behaviour and bioavailability of metals in soils, thereby exerts a major influence on their uptake by plant roots. Indian soils, representing the various soil types of tropics, were subjected to Ni treatment of different concentrations and equilibrated at room temperature. The Ni adsorbed by each soil was calculated as the difference between the amount of Ni present in the solution initially and that remaining after equilibration. Results indicated that all the soils under study follow Freundlich and linear adsorption isotherms with highly significant positive correlation. In general, adsorption capacity of the soils for $\mathrm{Ni}$ increased with an increase in $\mathrm{pH}$ of the soil, whereas, the reverse was found to be true for the rate of adsorption. Significant positive correlations $(p=0.1-0.001)$ were obtained between Freundlich's $\mathrm{K}$ (adsorption capacity) and $\mathrm{pH}, \mathrm{CEC}$ and $\mathrm{CaCO}_{3}$ content of the soils. Also, eight soils of Maharashtra, India, were found to fit in all the three adsorption isotherms, namely, Freundlich, Langmuir and linear. The distribution coefficient $\left(\mathrm{K}_{\mathrm{d}}\right)$ values of these soils, in general, increased with an increase in $\mathrm{pH}$ and $\mathrm{CEC}$ of the soils. Adsorption of Ni in soils followed the order: vertisol $>$ entisol $>$ alfisol/ultisol.
\end{abstract}

Keywords: adsorption, nickel, Indian soils, isotherm, distribution coefficient

\section{Introduction}

Nickel (Ni) is an important heavy metal, and pollution by $\mathrm{Ni}$ has gained importance due to the greater understanding of its persistence and toxicity in the ecosystems (Alemayehu and Lennartz, 2010). The effects of $\mathrm{Ni}$ exposure vary from skin irritation to damage of the nervous system and it is also a known carcinogen. Nickel may enter and accumulate in agricultural soils through the application of phosphate fertilizers, pesticides and other waste materials from industries like nickel-cadmium batteries, nickel electroplating, paints formulation, vegetable fat production, etc. The normal range of $\mathrm{Ni}$ in soils is $2-750 \mathrm{mg} \mathrm{kg}^{-1}$ and the normal range in plants is 0.02 $-5 \mathrm{mg} \mathrm{kg}^{-1}$ (Alloway, 1990). The passage of $\mathrm{Ni}$ from environment to animals and man involves the transfer of metal through soil-plant link in the terrestrial food chain and hence, the behaviour of $\mathrm{Ni}$ in soils and soil-plant system is of considerable environmental significance. The persistence of $\mathrm{Ni}$ in the soil and its reduction in mobility involve the phenomena of 
sorption, desorption, precipitation, complexation, oxidation/reduction and dissolution. Although all these reactions can occur simultaneously, adsorption mechanisms are known to be determinant in the control of metal availability and solubility in the soil (Sparks, 1999).

Adsorption of metals from the liquid phase into the solid phase is one of the most important chemical processes which affect the behaviour and bioavailability of metals in soils. This process controls the concentration of metal ions and complexes in the soil solution and thus can exert a major influence on their uptake by plant roots.

Adsorption of heavy metals in soils involves two mechanisms. One is non-selective adsorption, in which the metallic cations act as counter-ions in the diffuse layer; the other is selective adsorption, in which surface complexes are formed. The importance of each of these mechanisms depends on the metal and the type of soil (Lafuente et al., 2008). Knowledge on the adsorption mechanisms and their quantification are fundamental for the comprehension of polluter-metal movement in contaminated soils, providing possible alternatives for a preventive environment control (Mellis et al., 2004).

The $\mathrm{pH}$, cation exchange capacity and $\mathrm{CaCO}_{3}$ content of the soils are some of the important characteristics which affect the adsorption and subsequent plant uptake of Ni from soil. Soil organic matter exhibits a large number and variety of functional groups and high CEC values, which results in enhanced heavy metal retention ability, mostly by surface complexation, ion exchange and surface precipitation (Bradl, 2004).

Studies on the contamination of $\mathrm{Ni}$ in soils and plants have so far been restricted to highly industrialized temperate regions (Reddy and Dunn, 1986; AlHamdan and Reddy, 2006) and the quantitative data available on the fate of this pollutant in soils of subtropical and tropical regions of Asia, in general, and India, in particular are few.
In the present paper, the adsorption behaviour of $\mathrm{Ni}$ by different tropical soils of varying physicochemical characteristics, from different parts of India, was examined using Freundlich, Langmuir and linear adsorption isotherms to understand the likely availability of $\mathrm{Ni}$ to agricultural crop plants.

\section{Materials and Methods}

Soils from 13 places from different parts of India, varying in their physicochemical properties (Table 1) were selected for this study. They broadly represent the four typical soil types of tropics, namely, alfisol, ultisol, entisol and vertisol.

Sieved soils ( $1 \mathrm{~g})$ of each type were placed in centrifuge tubes at room temperature $\left(25 \pm 1^{\circ} \mathrm{C}\right)$ and $20 \mathrm{~mL}$ of $0.01 \mathrm{M} \mathrm{CaCl}_{2}$ containing different concentrations of $\mathrm{Ni}$ (ranging from 10 to $100 \mu \mathrm{g} \mathrm{mL}^{-1}$ ) were added and shaken for $1 \mathrm{~h}$ in a rotary shaker. The soils were then centrifuged at $3000 \mathrm{rpm}$ and filtered through Whatman No. 42 filter paper. The procedure followed here was that of Fontes and Gomes (2003) and there were four replicates for each concentration. The filtrates were analysed for $\mathrm{Ni}$ using GBC Model 932B+ atomic absorption spectrometer. The $\mathrm{Ni}$ adsorbed by each soil was calculated as the difference between the amount of Ni present in the solution initially and that remaining after equilibrium, as described by Garcia-Miragaya and Page (1978). The adsorption data of $\mathrm{Ni}$ by different soils were examined for the kind of adsorption isotherms they fit, namely, Freundlich, Langmuir or linear adsorption isotherms; their respective equations were as follows:

$$
\text { Langmuir: } \mathrm{C} / \mathrm{x} / \mathrm{m}=1 / \mathrm{kb}+\mathrm{C} / \mathrm{b}
$$

$$
\text { Linear: } \mathrm{x} / \mathrm{m}=\mathrm{a}+\mathrm{bC}
$$


Table 1. Physicochemical characteristics of experimental soils

\begin{tabular}{|c|c|c|c|c|c|c|c|c|}
\hline Soil & Soil Group & pH & $\begin{array}{l}\text { CEC } \\
{\left[\mathrm{c} \mathrm{mol}\left(\mathrm{p}^{+}\right) \mathrm{kg}^{-1}\right]}\end{array}$ & $\begin{array}{l}\text { Free } \mathrm{CaCO}_{3} \\
(\%)\end{array}$ & $\begin{array}{l}\text { Organic } \\
\mathrm{C}(\%)\end{array}$ & $\begin{array}{l}\text { Sand } \\
(\%)\end{array}$ & $\begin{array}{l}\text { Silt } \\
(\%)\end{array}$ & $\begin{array}{l}\text { Clay } \\
(\%)\end{array}$ \\
\hline Thrissur & Ultisol & 4.2 & 25.9 & 1.12 & 3.80 & 50.8 & 13.1 & 36.1 \\
\hline Phondaghat & Ultisol & 5.1 & 10.5 & 1.00 & 1.36 & 59.0 & 19.0 & 22.0 \\
\hline Dapoli & Ultisol & 5.5 & 19.3 & 0.75 & 0.20 & 37.0 & 29.0 & 34.0 \\
\hline Lanja & Alfisol & 5.9 & 14.6 & 1.25 & 1.80 & 18.0 & 17.4 & 64.6 \\
\hline Chittoor & Alfisol & 6.4 & 13.0 & 0.50 & 0.12 & 66.6 & 20.0 & 13.4 \\
\hline Mahad & Entisol & 6.6 & 31.6 & 3.00 & 1.36 & 36.8 & 51.8 & 11.4 \\
\hline Delhi & Entisol & 7.4 & 18.0 & 1.55 & 0.51 & 73.9 & 11.2 & 14.9 \\
\hline Pantnagar & Entisol & 7.8 & 24.4 & 2.30 & 1.68 & 24.0 & 45.0 & 31.0 \\
\hline Akola & Vertisol & 7.8 & 51.1 & 2.60 & 0.06 & 21.8 & 26.0 & 52.2 \\
\hline Amaravati & Vertisol & 8.1 & 50.0 & 5.05 & 0.84 & 6.5 & 27.4 & 66.1 \\
\hline Hatkanangale & Vertisol & 8.2 & 60.7 & 6.75 & 1.32 & 31.4 & 41.9 & 26.7 \\
\hline Jalna & Vertisol & 8.4 & 58.1 & 11.37 & 0.80 & 46.0 & 31.6 & 22.4 \\
\hline Jalgaon & Vertisol & 8.5 & 40.5 & 1.60 & 0.82 & 28.0 & 31.0 & 41.0 \\
\hline
\end{tabular}

where, $\mathrm{x} / \mathrm{m}=\mathrm{Ni}$ adsorbed $\left(\mu \mathrm{g} \mathrm{g}^{-1}\right.$ soil $)$

$$
\mathrm{C}=\mathrm{Ni} \text { concentration of equilibrium soil }
$$
solution $\left(\mu \mathrm{g} \mathrm{mL} \mathrm{L}^{-1}\right)$

Freundlich's $\mathrm{K}$ = adsorption capacity or degree of affinity ( $\mu \mathrm{g} \mathrm{Ni} \mathrm{g}^{-1}$ soil)

$$
\text { and } \mathrm{a}=\text { rate of adsorption }
$$

Langmuir's $\mathrm{k}=$ constant related to bonding energy

$$
\mathrm{b}=\text { adsorption maxima ( } \mathrm{mg} \mathrm{Ni}^{-1} \text { soil) }
$$

The Freundlich and Langmuir adsorption parameters were calculated for each soil and the relationships between these parameters and the soil properties such as $\mathrm{pH}, \mathrm{CEC}$, organic $\mathrm{C}, \mathrm{CaCO}_{3}$ and Clay contents were examined. The distribution coefficient $\left(\mathrm{K}_{\mathrm{d}}\right)$ of $\mathrm{Ni}$ for each soil was calculated (Reddy and Dunn, 1986; Anderson and Christensen ,1988; Covelo et al., 2004) using the following formula:

Distribution Coefficient $\left(\mathrm{K}_{\mathrm{d}}\right)=$ Amount of Ni adsorbed $\mathrm{g}^{-1}$ soil/Amount of $\mathrm{Ni}$ in solution $\mathrm{mL}^{-1}$.

Linear $\mathrm{a}, \mathrm{b}=$ constants 


\section{Results and Discussion}

Results indicate that all the soils under study followed Freundlich and linear adsorption isotherms with highly significant positive correlation (r). Comparatively, the soils followed Freundlich adsorption isotherm better than that of linear adsorption as indicated by higher $r$ values.

The intercepts of linear adsorption equations of different soils, considered as indicators of degree of affinity of the surface for Ni ranged from -109 for Thrissur soil ( $\mathrm{pH} 4.2$ ) to a maximum of 272 for Akola soil (pH 7.8). Echeverria et al. (1998) reported that Langmuir monolayer and Freundlich distribution coefficients were higher in basic soils than in acidic soils. A similar trend was observed in the Freundlich adsorption isotherms as indicated by a very small $\mathrm{K}$ value (degree of affinity or relative adsorption capacity) of 3.72 for the acidic soil of Thrissur and the highest value of 316.2 for the basic soil of Jalna (Table 2). Typical linear (plot of $\mathrm{x} / \mathrm{m}$ Vs C) and Freundlich (plot of $\log \mathrm{x} / \mathrm{m}$ Vs $\mathrm{C}$ ) adsorption isotherms are shown in Figures 1A and 1B, respectively.

The values of Freundlich adsorption parameters ' $\mathrm{K}$ ' (adsorption capacity) and 'a' (rate of adsorption) are shown in Table 2. In general, adsorption capacity of the soils for $\mathrm{Ni}$ increased with an increase in $\mathrm{pH}$ of the soil, whereas, the reverse was found to be true for the rate of adsorption. Our findings are in agreement with earlier work of Mellis et al. (2004), who also reported that independent of the treatment, the adsorption of $\mathrm{Ni}$ increased with increasing $\mathrm{pH}$ of the soils.

The coefficient of correlation of Freundlich adsorption parameters ' $\mathrm{K}$ ' and ' $\mathrm{a}$ ' with soil properties are shown in Table 3.

Significant positive correlations $(p=0.1-0.001)$ between $\mathrm{K}$ and soil properties such as $\mathrm{pH}, \mathrm{CEC}$ and $\mathrm{CaCO}_{3}$ content were obtained. However, organic $\mathrm{C}$ and clay contents did not show any significant correlations. Also, significant negative correlations were obtained between ' $\mathrm{a}$ ' and $\mathrm{pH}, \mathrm{CEC}$ of the soils.
Table 2. Values of Freundlich parameters for different experimental soils.

\begin{tabular}{lll}
\hline Soil & $\begin{array}{l}\text { Adsorption capacity } \\
(\mathbf{K})\left(\mu \mathrm{g} \mathrm{g}^{-1} \text { soil }\right)\end{array}$ & $\begin{array}{l}\text { Rate of adsorption } \\
(\mathbf{a})\end{array}$ \\
\hline Thrissur & 3.72 & 1.23 \\
Phondaghat & 12.88 & 0.85 \\
Dapoli & 33.90 & 0.75 \\
Lanja & 25.12 & 0.67 \\
Chittoor & 16.22 & 0.78 \\
Mahad & 81.28 & 0.62 \\
Delhi & 64.57 & 0.68 \\
Pantnagar & 125.90 & 0.55 \\
Akola & 309.00 & 0.58 \\
Amaravati & 281.80 & 0.65 \\
Hatkanangale & 295.10 & 0.65 \\
Jalna & 316.20 & 0.63 \\
Jalgaon & 239.90 & 0.58 \\
\hline
\end{tabular}

Table 3. Coefficient of correlation of Freundlich adsorption parameters with soil properties

\begin{tabular}{lll}
\hline Soil property (unit) & K & a \\
\hline $\mathrm{pH}$ & $0.946^{* * *}$ & $-0.842^{* * *}$ \\
$\mathrm{CEC}\left[\mathrm{c} \mathrm{mol}\left(\mathrm{p}^{+}\right) \mathrm{kg}^{-1}\right]$ & $0.961^{* * *}$ & $-0.842^{* *}$ \\
Org. C (\%) & $\mathrm{NS}$ & $\mathrm{NS}$ \\
Clay (\%) & $\mathrm{NS}$ & $\mathrm{NS}$ \\
$\mathrm{CaCO}_{3}(\%)$ & $0.659^{*}$ & NS
\end{tabular}

*: Significant at $\mathrm{p}=0.1 ; * *$ : Significant at $\mathrm{p}=0.01 ; * * *$ : Significant at $p=0.001 ;$ NS: Not significant 

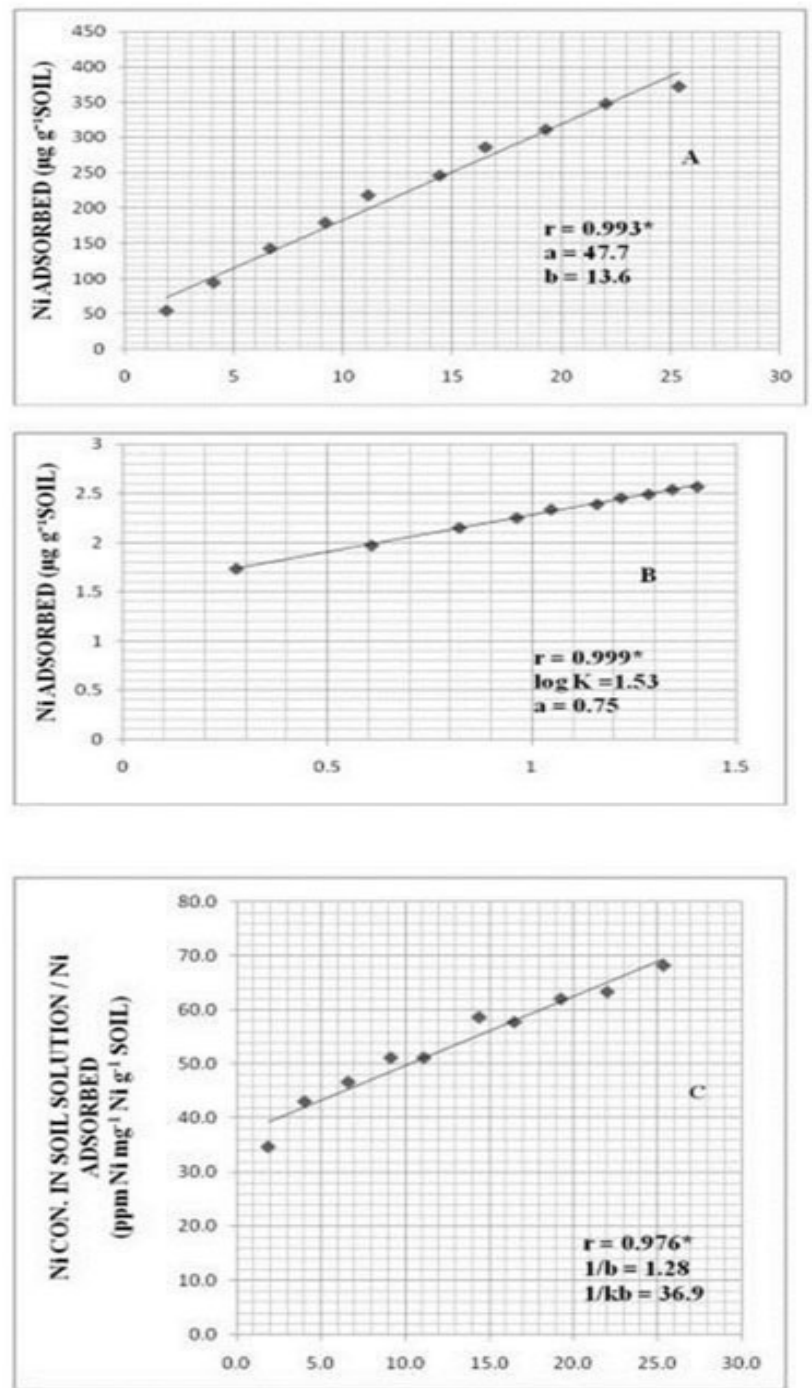

Ni CONCENTRATION IN SOIL SOLUTION $\left(\mu \mathrm{g} \mathrm{mL}^{-4}\right)$

Figure 1. Adsorption of nickel in Dapoli soil A) Linear isotherm B) Freundlich isotherm

C) Langmuir isotherm $*: p=0.001$. 
The current findings are in agreement with earlier studies of Gomes et al. (2001) and Adhami et al. (2008), who have reported that $\mathrm{pH}$ and CEC of soils played major role and were positively correlated with $\mathrm{Ni}$ adsorption of soils. According to Adhami et al. (2008), adsorption maxima of Langmuir adsorption isotherm of Ni was correlated with CEC of different soils; further, $\mathrm{pH}, \mathrm{CEC}$, clay and organic matter contents were the main factors which regulate the retention of $\mathrm{Ni}$ in soils. Shi et al. (2012) have reported that Ni adsorption on soil organic matter (SOM) was dominant in the short term and the slow transfer of adsorbed $\mathrm{Ni}$ to $\mathrm{Ni}$ - layered double hydroxide (Ni-LDH) phases with longer reaction times.

Among the 13 experimental soils selected for the study, eight soils of Maharashtra, India, were found to fit in all the three adsorption isotherms, namely, Freundlich, Langmuir and linear and a typical Langmuir adsorption isotherm (plot of $\mathrm{C} / \mathrm{x} / \mathrm{m}$ Vs C) is shown in Figure 1C.

However, in all these eight soils, Freundlich's adsorption isotherm was predominant ( $r=0.987$ to 0.999$)$ followed by linear $(r=0.974$ to 0.993$)$ and least by Langmuir $(r=$ 0.675 to 0.976 ) as shown in Table 4 . The predominance of Freundlich adsorption model for Ni adsorption in soils is in agreement with earlier studies of Al-Hamden and Reddy (2006) and Sunil Kumar et al. (2009).

The Freundlich's K values (Table 2) varied from 12.88 for Phondaghat soil of $\mathrm{pH} 5.1$ to 316.20 for Jalna soil of $\mathrm{pH}$ 8.4. Similar trend was followed in Langmuir adsorption isotherm where adsorption maxima (b) values (Table 4) were found to be minimum for Phondaghat soil $(0.78)$ and maximum for Jalna soil (2.63). In general, the adsorption of $\mathrm{Ni}$ in different soil types followed the order: vertisol $>$ entisol $>$ alfisol/ultisol.

Earlier researchers have reported about the enhanced sorption of metals with increasing soil $\mathrm{pH}$ (Harter, 1983; Msaky and Calvet,1990; Basta and Tabatai, 1992; Raghupathi and Vasuki, 1993), which is attributed to the generation of $\mathrm{pH}$-dependent sites on colloids, reduced competition with $\mathrm{H}$-ions and a change in the hydrolysis state of ions in solution. According to Gomes et al. (2001), soils from alfisol and ultisol orders having higher $\mathrm{pH}$ values were the ones with highest relative capacity to adsorb metal ions. Soil with high CEC resulted in greater adsorption of $\mathrm{Ni}$ and higher $\mathrm{Kd}$ value than the soil having lower CEC.

The findings obtained in the present study are in agreement with Reddy and Dunn (1986), who reported that the abundance of exchange sites available for $\mathrm{Ni}$ on high CEC soils were responsible for such observation. Jalali and Moharrami (2007) also have reported that soil with highest CEC showed the highest sorption capacity of the elements studied.

The enhancement in $\mathrm{Ni}$ adsorption at higher alkaline $\mathrm{pH}$ levels may be attributed to the hydroxide precipitation reactions with $\mathrm{Ni}^{2+}$ and $\mathrm{NiOH}^{+}$species as reported by Sen Gupta and Bhattacharyya (2006). Also, at elevated $\mathrm{pH}$, the presence of carbonates may have led to an increase in the retention of $\mathrm{Ni}$. When the carbonate content and the $\mathrm{pH}$ are high, heavy metals are retained in the soil mainly as carbonate salts.

When the $\mathrm{pH}$ of the soil decreases, carbonate dissolution increases and ionic exchange is the principal retention mechanism of heavy metals (Plassard et al., 2000; Elzahabi and Yong, 2001).

The distribution coefficient $\left(\mathrm{K}_{\mathrm{d}}\right)$ values for the eight Maharashtran soils are presented in Table 5.

In general, $\mathrm{K}_{\mathrm{d}}$ values increased with an increase in $\mathrm{pH}$ and CEC of the different soils. Distribution coefficients characterize the capacity of the soil to retain a solute and the capacity of a solution phase to mobilize it when it is retained (Reddy and Dunn, 1986). High Kd values indicate that the metal $(\mathrm{Ni})$ has been retained by the solid phase through sorption reactions, while low $\mathrm{Kd}$ values show that high concentrations of metal remain in solution.

As compared to alkaline soils, the adsorption capacity of Ni in acidic soils is low (Table 2). The findings are similar to that of $\mathrm{Cd}$ adsorption in various acidic soils of 
Table 4. Langmuir adsorption equation for Ni in different soils of Maharashtra

\begin{tabular}{lclll}
\hline Soil & $\mathbf{p H}$ & Langmuir equation & $\begin{array}{l}\text { Correlation } \\
\text { coefficient }(\mathbf{r})\end{array}$ & $\mathbf{b}$ \\
\hline Phondaghat & 5.1 & $\mathrm{C} / \mathrm{x} / \mathrm{m}=104+1.3 \mathrm{C}$ & $0.675^{*}$ & 0.78 \\
Dapoli & 5.5 & $\mathrm{C} / \mathrm{x} / \mathrm{m}=36.9+1.28 \mathrm{C}$ & $0.976^{* * *}$ & 0.78 \\
Mahad & 6.6 & $\mathrm{C} / \mathrm{x} / \mathrm{m}=6.85+1.07 \mathrm{C}$ & $0.969^{* * *}$ & 0.93 \\
Akola & 7.8 & $\mathrm{C} / \mathrm{x} / \mathrm{m}=3.18+0.52 \mathrm{C}$ & $0.970^{* * *}$ & 1.92 \\
Amaravati & 8.1 & $\mathrm{C} / \mathrm{x} / \mathrm{m}=3.88+0.39 \mathrm{C}$ & $0.849^{* *}$ & 2.56 \\
Hatkanangale & 8.2 & $\mathrm{C} / \mathrm{x} / \mathrm{m}=3.22+0.43 \mathrm{C}$ & $0.962^{* * *}$ & 2.33 \\
Jalna & 8.4 & $\mathrm{C} / \mathrm{x} / \mathrm{m}=3.32+0.38 \mathrm{C}$ & $0.877^{* * *}$ & 2.63 \\
Jalgaon & 8.5 & $\mathrm{C} / \mathrm{x} / \mathrm{m}=4.75+0.54 \mathrm{C}$ & $0.969^{* * *}$ & 1.85 \\
\hline
\end{tabular}

$\mathrm{C}$ : Ni concentration of equilibrium soil solution $\left(\mu \mathrm{g} \mathrm{ml}^{-1}\right) ; \mathrm{x} / \mathrm{m}$ : Ni adsorbed ( $\mathrm{mg} \mathrm{g}^{-1}$ soil); b: adsorption maxima (mg Ni $\mathrm{g}^{-1}$ soil); *: Significant at $p=0.05 ; * *$ : Significant at $p=0.01 ; * *$ : Significant at $p=0.001$

India (Ramachandran and D'Souza, 1999). Lafuente et al. (2008) reported about the similarity in the adsorption behaviour of $\mathrm{Cd}$ and $\mathrm{Ni}$ in different soil samples. The presence of $\mathrm{Al}^{3+}$ in acidic soils and its competition for exchange sites might have resulted in reduced $\mathrm{Ni}$ adsorption in these soils like $\mathrm{Cd}$ (Cavallaro and McBride, 1978). According to Tan (2011), at low $\mathrm{pH}$, majority of $\mathrm{Ni}$ (II) was adsorbed in the inter layers of Ca-montmorillonite co-ordianted by six water molecules in an octahedron as an outer-sphere complex; on the other hand, at higher $\mathrm{pH}$, inner-sphere surface complexes are formed. Also, the Fe-oxides present in acidic soils may lead to decreased $\mathrm{Ni}$ adsorption by blocking access of $\mathrm{Ni}$ to exchange sites as reported by Cowan et al. (1992) and Zachara et al. (1992) for Cd. The acidic soils selected in the present study contained high amount of sesquioxides $\left(\mathrm{Fe}_{2} \mathrm{O}_{3}+\right.$ $\mathrm{Al}_{2} \mathrm{O}_{3}$ ) of $17 \%$ as compared to alkaline soils (below $8 \%$ ). Hence, the presence of high amounts of $\mathrm{Al}^{3+}$ and $\mathrm{Fe}^{3+}$ may be responsible for the low adsorption capacity of $\mathrm{Ni}$ in these soils.
Table 5. Distribution coefficient $\left(\mathrm{K}_{\mathrm{d}}\right)$ of nickel for different soils of Maharashtra

\begin{tabular}{lclc}
\hline Soil & $\mathrm{pH}$ & $\begin{array}{l}\mathrm{CEC} \\
{\left[\mathrm{c} \mathrm{mol}\left(\mathrm{p}^{+}\right) \mathrm{kg}^{-1}\right]}\end{array}$ & $\begin{array}{l}\mathrm{K}_{\mathrm{d}} \\
\left(\mathrm{mL} \mathrm{g}^{-1}\right)\end{array}$ \\
\hline Phondaghat & 5.1 & 10.5 & 6.7 \\
Dapoli & 5.5 & 19.3 & 13.7 \\
Mahad & 6.6 & 31.6 & 33.3 \\
Akola & 7.8 & 51.1 & 128 \\
Amaravati & 8.1 & 50.0 & 185 \\
Hatkanangale & 8.2 & 60.7 & 188 \\
Jalna & 8.4 & 58.1 & 212 \\
Jalgaon & 8.5 & 40.5 & 201 \\
\hline
\end{tabular}




\section{Conclusions}

The soils selected for the study, in general, fit in Freundlich adsorption isotherm better than either Langmuir or linear adsorption isotherm for $\mathrm{Ni}$ adsorption. High $\mathrm{pH}$, alkaline soils favoured high adsorption of $\mathrm{Ni}$, thereby less availability of $\mathrm{Ni}$ for plant uptake, whereas, acid soils adsorbed less $\mathrm{Ni}$ and more $\mathrm{Ni}$ was present as $\mathrm{Ni}^{2+}$ in solution, which may lead to more availability of Ni for plant uptake. The study further indicates that $\mathrm{Ni}$ adsorption is mainly dependent on $\mathrm{pH}, \mathrm{CEC}$ and $\mathrm{CaCO}_{3}$ content of the soils. Adsorption of $\mathrm{Ni}$ in tropical soils follows the order: vertisol $>$ entisol $>$ alfisol/ultisol

\section{References}

Adhami, E., Salmanpour, A., Omidi, A., Khosravi, N. ,Ghasemi-Fasaei, R., Maftoun, M. 2008. Nickel adsorption characteristics of selected soils as related to some soil properties. Soil and Sedim. Contam. 17, 643-653.

Alemayehu, E. , Lennartz, B. 2010. Adsorptive removal of nickel from water using volcanic rocks. Appl. Geochem. 25, 1596-1602.

Al-Hamdan, A.Z., Reddy, K.R. 2006. Adsorption of heavy metals in glacial till soil. Geotech. Geol. Engin. 24, 1679-1693.

Alloway, B.J. 1990. Heavy Metals in Soils. Blackie and Sons Ltd. (Publ.), U.K., 339 p.

Anderson, P.R., Christensen, T.H. 1988. Distribution coefficients of $\mathrm{Cd}, \mathrm{Co}, \mathrm{Ni}$ and $\mathrm{Zn}$ in soils. J. Soil Sci. 39, 15- 22.

Basta, N.T., Tabatabai, M.A. 1992. Effect of cropping systems on adsorption of metals by soils: II. Effect of pH. Soil Sci. 153, 195-204.

Bradl, H.B. 2004. Adsorption of heavy metal ions on soils and soil constituents. J. Coll. Interf. Sci. 277, $1-18$.

Cavallaro, N., McBride, M.B. 1978. Copper and cadmium adsorption characteristics of selected acid and calcareous soils. Soil Sci. Soc. Am. J. 42, 550-556.

Covelo, E.F., Andrade, M.L., Vega, F.A. 2004. Simultaneous adsorption of $\mathrm{Cd}, \mathrm{Cr}, \mathrm{Cu}, \mathrm{Ni}, \mathrm{Pb}$ and $\mathrm{Zn}$ by different soils. J. Food, Agri. Environ. 2, 244-250.

Cowan, C.E., Zachara, J.M., Smith, S.C., Resch, C.T. 1992. Individual sorbent contributes to cadmium sorption on ultisols of mixed mineralogy. Soil Sci. Soc. Am. J. 56, 1084-1094.

Echeverria, J.C., Morera, M.T., Mazkiaran, C., Garrido, J.J. 1998. Competitive sorption of heavy metal by soils: isotherms and fractional and factorial experiments. Environ. Pollut. 101, 275-284.

Elzahabi, M., Yong, R.N. 2001. pH influence on sorption characteristics of heavy metal in the vadose zone. Eng. Geol. 60, 61-68.

Fontes, M.P.F., Gomes, P.C. 2003. Simultaneous competitive adsorption of heavy metals by a mineral matrix of tropical soils. Appl. Geochem. $18,795-804$.

Garcia-Miragaya, J., Page, A.L. 1978. Sorption of trace quantities of cadmium by soils with different chemical and mineralogical composition. Water Air Soil Pollut. 9, 289-299.

Gomes, P.C., Fontes, M.P.F., daSilva, A.G., Mendonca, E.d.S., Netto, A.R. 2001. Selectivity sequence and competitive adsorption of heavy metals in Brazilian soils. Soil Sci. Soc. Am. J. 65, 1115-1121.

Harter, R.D. 1983. Effect of soil pH on adsorption of lead, copper, zinc and nickel. J. Soil Sci. Soc. Am. $47,47-51$ 
Jalali, M., Moharrami, S. 2007. Competitive adsorption of trace elements in calcareous soils of western Iran. Geoderma. 140, 156-163.

Kumar, S., Ghosh, S., Mukherjee, S., Sarkar, S. 2009. Chromium and nickel migration study through fine grained soil. J. Hazard. Mat. 170, 1192-1196.

Lafuente, A.L., Gonzalez, C., Quintana, J.R., Vazquez, A., Romero, A. 2008. Mobility of heavy metals in poorly developed carbonate soils in Mediterranean region. Geoderma. 145, 238-244.

Mellis, E.V., Pessoa da Cruz, M.C., Casagrande, J.C. 2004. Nickel adsorption by soils in relation to $\mathrm{pH}$, organic matter and iron oxides. Sci. Agric. (Piracicaba, Braz.). 61, 190-195.

Msaky, J.J., Calvet, R. 1990. Adsorption behaviour of copper and zinc in soils, influence of $\mathrm{pH}$ on adsorption characteristics. Soil Sci. 150, 513-522.

Plassard, F., Winiarski, T., Petit-Ramel, M. 2000. Retention and distribution of three heavy metals in a carbonated soil: comparison between batch and unsaturated column studies. J. Contam. Hydrol. $42,99-111$.

Raghupathi, H.B., Vasuki, N. 1993. Copper adsorption behaviour of some soils. J. Indian Soc. Soil Sci. 41, 70-74.
Ramachandran, V., D’Souza, T.J. 1999. Adsorption of cadmium by Indian soils. Water Air and Soil Pollut. 111, 225-234.

Reddy, M.R., Dunn, S.J. 1986. Distribution coefficients for nickel and zinc in soils. Environ. Pollut. (Series B). 11, 303-313.

Sen Gupta, S., Bhattacharyya, K.G. 2006. Adsorption of Ni(II) on clays. J. Coll. Interf. Sci. 295, 21-32.

Shi, Z., Peltier, E., Sparks, D.L. 2012. Kinetics of Ni sorption in soils: Roles of soil organic matter and Ni precipitation. Environ. Sci. Technol. 46, 22122219.

Sparks, D.L. 1999. Kinetics and mechanisms of chemical reactions at the soil mineral/water interface, in: Sparks, D.L. (Ed.), Soil physical chemistry, CRC Press, New York, pp. 135-191.

Tan, X.L., Hu, J., Montavon, G., Wang, X.K. 2011. Sorption speciation of nickel(II) onto Camontmorillonite: Batch, EXAFS techniques and modeling. Dalton Transactions. 40, 10953-10960.

Zachara, J.M., Smith, S.C., Resch, C.T., Cowan, C.E. 1992. Cadmium sorption to soil separates containing layer silicates and iron and aluminum oxides. Soil Sci. Soc. Am. J. 56, 1074-1084. 